Check for updates

Cite this: Chem. Commun., 2020, 56, 12589

Received 10th June 2020,

Accepted 26th August 2020

DOI: $10.1039 / \mathrm{d} 0 \mathrm{cc} 04065 \mathrm{~g}$

rsc.li/chemcomm

\section{Synthetic access to a phosphorescent non-palindromic pincer complex of palladium by a double oxidative addition - comproportionation sequence $\dagger$}

\author{
Wolfram Feuerstein (D) and Frank Breher (D) *
}

\begin{abstract}
A highly luminescent non-palindromic $\left[\left(\mathrm{C}^{\wedge} \mathrm{C}^{\wedge} \mathrm{N}\right) \mathrm{Pd}\right]$ pincer complex forms upon reacting pyridine-substituted 2,2'-diiodo-biphenyl with $\left[\mathrm{Pd}\left(\mathrm{PPh}_{3}\right)_{4}\right]$. This case study establishes for the first time that the title compound is formed via a double oxidative addition comproportionation sequence. DFT and TDDFT calculations complement mechanistic and photophysical characterizations.
\end{abstract}

Pincer complexes ${ }^{1}$ of platinum and gold gained increasing attention during the past 30 years due to their simple preparation $^{2}$ and appealing photophysical properties making them interesting for applications in photocatalysis ${ }^{3}$ and electroluminescent devices, ${ }^{4,5}$ but in the field of catalysis ${ }^{6}$ and biomedical applications ${ }^{7}$ as well. Contrasting the plethora of investigations concerned with diphenylpyridine-based $\left(\mathrm{C}^{\wedge} \mathrm{N}^{\wedge} \mathrm{C}\right)$ pincer complexes, only one example of palladium (1) has been published in the literature until now (Fig. 1). ${ }^{8}$ Missing investigations on the $\left(\mathrm{C}^{\wedge} \mathrm{N}^{\wedge} \mathrm{C}\right)$ palladium complexes are, among other, mainly caused by the lack of feasible methods for their synthesis reported so far, and the fact that the only photophysically investigated complex $\left[\left(\mathrm{C}^{\wedge} \mathrm{N}^{\wedge} \mathrm{C}\right) \mathrm{Pd}^{\mathrm{II}}(\mathrm{py})\right]$ (py = pyridine) exhibits only poor luminescence properties in contrast to its platinum analogue. ${ }^{9}$ Nevertheless, there are few reports on other emissive Pd complexes. ${ }^{10}$ Che and co-workers developed tetradentate $\left(\mathrm{C}^{\wedge} \mathrm{C}^{\wedge} \mathrm{N}^{\wedge} \mathrm{O}\right)$ ligands and applied them for the synthesis of $\mathrm{Pd}^{\mathrm{II}}$ complexes highly phosphorescent in solution at room temperature. ${ }^{11}$ A tetradentate ligand scaffold is certainly superior to tridentate pincers regarding the ability to suppress vibrational relaxation pathways of photoexcited states due to the even more rigid nature. However, tetradentate ligands occupy all coordination sites of a square-planar complex, which may not be desirable in view of potential catalytic applications. ${ }^{12}$

Karlsruhe Institute of Technology (KIT), Institute of Inorganic Chemistry,

Division Molecular Chemistry, Engesserstr. 15, 76131 Karlsruhe, Germany.

E-mail: breher@kit.edu

$\dagger$ Electronic supplementary information (ESI) available: Experimental details, NMR data, X-ray crystal structure data, quantum chemical calculations. CCDC 1986487 and 1986490. For ESI and crystallographic data in CIF or other electronic format see DOI: 10.1039/d0cc04065g
For example, the $\left(\mathrm{C}^{\wedge} \mathrm{N}^{\wedge} \mathrm{C}\right)$ moiety was proven to show very promising chemical properties at ligated $\mathrm{Au}^{\mathrm{III}}$ centres making them interesting for new chemical transformations. ${ }^{13}$

In 2015, Nevado and co-workers described a nonpalindromic ${ }^{12,14}$ biphenyl-based $\left(\mathrm{C}^{\wedge} \mathrm{C}^{\wedge} \mathrm{N}\right)$ ligand employed for cyclometalated $\mathrm{Au}^{\mathrm{III}}$ complexes (2 in Fig. 1). ${ }^{15}$ The nonpalindromic $\left(\mathrm{C}^{\wedge} \mathrm{C}^{\wedge} \mathrm{N}\right)$ pincer ligand differs from the palindromic $\left(\mathrm{C}^{\wedge} \mathrm{N}^{\wedge} \mathrm{C}\right)$ motif regarding chemical properties due to the stronger trans influence of the carbon donor of the central phenyl ring. ${ }^{15,16}$ In addition, the $\left[\left(\mathrm{C}^{\wedge} \mathrm{C}^{\wedge} \mathrm{N}\right) \mathrm{Au}^{\mathrm{III}}\right]$ complexes outperform the majority of $\left[\left(\mathrm{C}^{\wedge} \mathrm{N}^{\wedge} \mathrm{C}\right) \mathrm{Au}^{\mathrm{III}}\right]$ analogues regarding emission quantum yields making them attractive for optoelectronic devices. ${ }^{17}$ The higher emission efficiency was traced back to stronger ligand field splitting of the non-palindromic $\left(\mathrm{C}^{\wedge} \mathrm{C}^{\wedge} \mathrm{N}\right)$ scaffold compared to the $\left(\mathrm{C}^{\wedge} \mathrm{N}^{\wedge} \mathrm{C}\right)$ analogue ( $c f$. Section $\mathrm{S} 5$, $\mathrm{ESI} \dagger$ for an in-depth discussion). ${ }^{15,18}$

Here, we present a simple procedure for the preparation of a non-palindromic $\left[\left(\mathrm{C}^{\wedge} \mathrm{C}^{\wedge} \mathrm{N}\right) \mathrm{Pd}^{\mathrm{II}}\right]$ complex based on a double oxidative addition of $2,2^{\prime}$-diiodobiphenyl substituted in 3-position with pyridine. This simple high-yield synthesis of a palladium(II) pincer complex 3 employing two phenyl rings and one pyridine donor makes this structural motif accessible for investigations and applications, which are until now mainly covered by platinum, gold and other transition metals. ${ }^{19} \mathrm{We}$

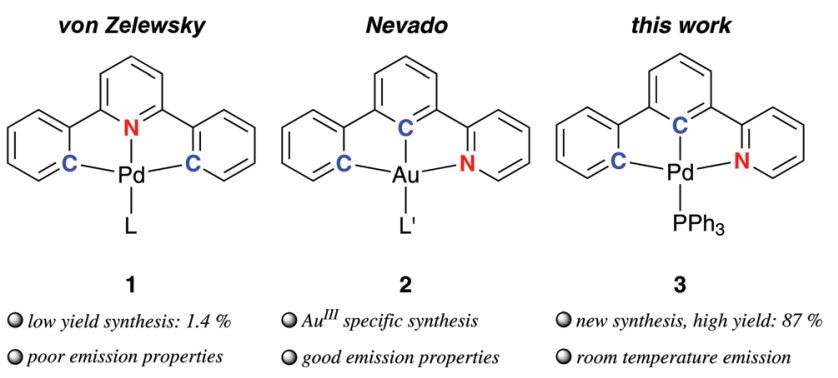

Fig. $1\left[\left(C^{\wedge} N^{\wedge} C\right) P d^{\prime \prime}\right]$ pincer complex $1\left(L=S E t_{2}\right.$, pyridine) and $\left[\left(C^{\wedge} C^{\wedge} N\right) A u^{\prime \prime \prime}\right]$ complexes $2\left(L^{\prime}=C l, F\right.$, acetylide, aryl) reported in the literature; complex $\mathbf{3}$ described in this study. 


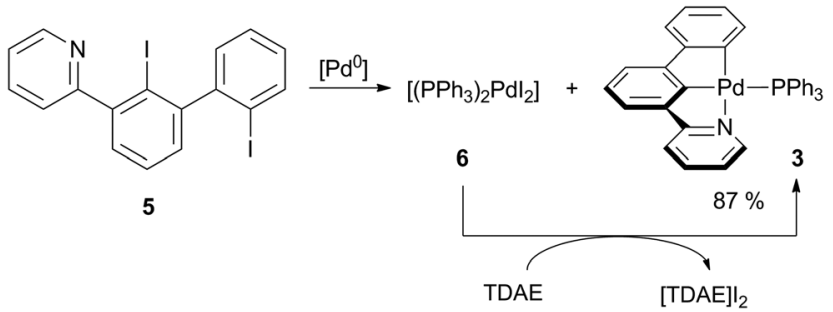

Scheme 1 Synthesis of $\left[\left(\mathrm{C}^{\wedge} \mathrm{C}^{\wedge} \mathrm{N}\right) \mathrm{Pd}^{\prime \prime}\right]$ complex 3. $\left[\mathrm{Pd}^{0}\right]=\left[\mathrm{Pd}\left(\mathrm{PPh}_{3}\right)_{4}\right]$ Conditions: toluene, $100{ }^{\circ} \mathrm{C}, 4 \mathrm{~h}$

use the analysis of photophysical properties as tool to shed light on the non-palindromic nature and impact of the $\left(\mathrm{C}^{\wedge} \mathrm{C}^{\wedge} \mathrm{N}\right)$ motif.

In a recent study, we have described the synthesis of pyridine-substituted $2,2^{\prime}$-diiodobiphenyl $\mathbf{5}$ as suitable preligand for the preparation of $\left[\left(\mathrm{C}^{\wedge} \mathrm{C}^{\wedge} \mathrm{N}\right) \mathrm{Au}^{\mathrm{III}}\right]$ complexes. ${ }^{20}$ Our initial intention was to use this diiodobiphenyl for the preparation of a $\mathrm{Pd}^{\mathrm{IV}}$ complex by double oxidative addition of $\mathrm{Pd}^{0}$ into both iodophenyl groups of $\mathbf{5}$. Bautista and co-workers reported on the oxidative addition of aryl iodides to $\mathrm{Pd}^{\mathrm{II}}$ to readily happen if the aryl iodide exhibits a functional group, which is able to coordinate to the $\mathrm{Pd}^{\mathrm{II}}$ centre. ${ }^{21}$ Thus, we reacted 5 with $\left[\mathrm{Pd}\left(\mathrm{PPh}_{3}\right)_{4}\right]$ in toluene (Scheme 1).

Upon heating, the formerly yellow solution turned dark red (Fig. S1, ESI $\dagger$ ). After workup, two species could be isolated in equal amounts by manually picking crystals: $\left[\left(\mathrm{PPh}_{3}\right)_{2} \mathrm{PdI}_{2}\right](6)$ and the palladium(II) pincer complex $\mathbf{3}$.

Full conversion of pre-ligand $\mathbf{5}$ was achieved by addition of one equivalent of tetrakis(dimethylamino)ethylene (TDAE) to reduce 6 in situ. ${ }^{22}$ Following this procedure, the pincer complex 3 was obtained in $87 \%$ overall yield in form of a yellow microcrystalline solid, which is luminescent under UV irradiation. Instead of $\left[\mathrm{Pd}\left(\mathrm{PPh}_{3}\right)_{4}\right]$, the dichloride $\left[\left(\mathrm{PPh}_{3}\right)_{2} \mathrm{PdCl}_{2}\right]$ may also be used when employing two equivalents TDAE.

The structure of 3 in the solid-state (Fig. 2) shows the palladium centre being coordinated in a distorted squareplanar fashion. The long Pd-P bond length of $236.8 \mathrm{pm}$ is

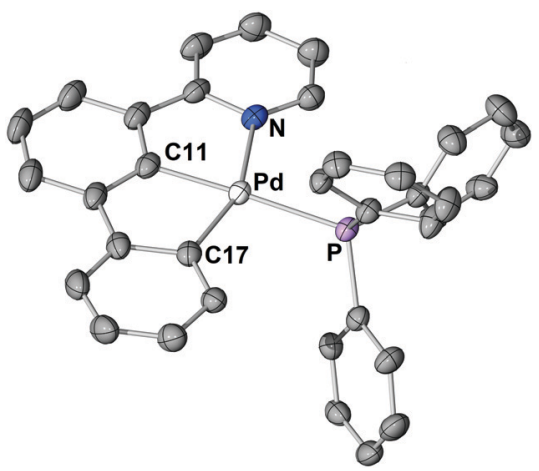

Fig. 2 Molecular structure of $\mathbf{3}$. Thermal ellipsoids are drawn at the $30 \%$ probability level. Hydrogen atoms are omitted for clarity. Only one molecule of the asymmetric unit is shown. Selected bond lengths (pm) and angles $\left(^{\circ}\right)$ : Pd-P 236.8(9), Pd-N 218.8(3), Pd-C11 197.3(4), Pd-C17 204.0(4), $\mathrm{N}-\mathrm{Pd}-\mathrm{C} 11$ 78.3(2), C11-Pd-C17 79.7(2). indicative for the strong trans influence of the carbon donor of the central phenyl ring and is comparable to the Pd-P bond length of typical $\mathrm{Pd}^{0}$ phosphine complexes. ${ }^{23}$ The calculated (RI-TPSS-D3(BJ)/def2-TZVP) Pd-P bond length of the hypothetical palindromic analogue $\left[\left(\mathrm{C}^{\wedge} \mathrm{N}^{\wedge} \mathrm{C}\right) \mathrm{Pd}^{\mathrm{II}} \mathrm{PPh}_{3}\right]$ was found to be $224 \mathrm{pm}$, i.e., $12 \mathrm{pm}$ shorter than experimentally found for 3 (calculated: $236 \mathrm{pm}$ ).

The simultaneous formation of pincer complex 3 in oxidation state + II and the diiodide 6 a priori suggested the intermediary formation of a $\mathrm{Pd}^{\mathrm{IV}}$ species and their comproportionation with not yet reacted $\mathrm{Pd}^{0}$ precursors. In principle, a bimetallic process involving the oxidative addition of two different metal centres into the two iodophenyl groups of $\mathbf{5}$ and subsequent intramolecular transmetalation could also be plausible. Such a bimetallic process should lead to a mixture of non-, mono- and diactivated $\mathbf{5}$ and derived products. However, the reaction compiled in Scheme 1 always yielded equal amounts of 3 and diiodide 6 with approximately $50 \%$ conversion of pre-ligand 5 , which disagrees with a bimetallic mechanism.

To shed further light on this reaction, we performed a control experiment and reacted 2,2'-diiodobiphenyl (S1) with $\left[\mathrm{Pd}\left(\mathrm{PPh}_{3}\right)_{4}\right]$ (Scheme S2, ESI $\dagger$ ) upon which the diiodide 6 formed as well. However, the other product(s) of this reaction, a yellow solid, we were not able to identify. ${ }^{31} \mathrm{P}$ NMR spectroscopic investigations showed more than ten different NMR signals. Thus, the lateral pyridine donor of $\mathbf{5}$ is crucial for the formation of 3.

We further investigated the mechanistic pathway in more detail by DFT calculations (Scheme 2). Additional pathways are discussed in the Supporting Information (Section S6, ESI $\dagger$ ).

$\left[\mathrm{Pd}\left(\mathrm{PPh}_{3}\right)_{4}\right]$ is known to lose one or two ligands upon solvation making the $\mathrm{Pd}^{0}$ atom reactive for oxidative addition. ${ }^{24}$ We assume that, in a first step, $\left[\mathrm{Pd}^{\mathrm{O}}\left(\mathrm{PPh}_{3}\right)_{3}\right]$ oxidatively adds into the C-I bond of the central $\left(\mathbf{B}_{c i s}\right)$ or lateral $\left(\mathbf{B B}_{c i s}\right)$ iodophenyl group of $\mathbf{5}$ with loss of one $\mathrm{PPh}_{3}$ ligand (L). A coordination of $\mathrm{Pd}^{0}$ to the pyridine donor $\left(\left[\mathbf{5}-\mathbf{P d L}_{3}\right]\right)$ does probably not precede a central addition since the hard donor pyridine will most likely not replace the softer $\mathrm{PPh}_{3}$. Interestingly, the formation of $\mathbf{B}_{c i s}$ is slightly favoured over $\mathbf{B B}_{\text {cis }}$ although the former is more sterically hindered. However, we identified dispersion interactions responsible for the opposite finding since optimization of structures without dispersion-corrected $\mathrm{DFT}^{25}$ predicts the lateral addition to be favoured by $-10.9 \mathrm{~kJ} \mathrm{~mol}^{-1}$. Dispersion interaction was shown to often be responsible for chemical properties standing in contrast to considerations only based on a molecule's bulk, e.g. the dimerization of the (bulky) tert-butyl substituted Gomberg radical. $^{26}$

After a first oxidative addition $¥$ and cis-trans isomerization $\left(\mathbf{B}_{\text {trans }} / \mathbf{B B}_{\text {trans }}\right)$ one $\mathrm{PPh}_{3}$ is displaced leading to the $\mathrm{Pd}^{\mathrm{II}}$ species $\mathbf{C}_{\text {trans }}$ and $\mathbf{C C}_{\text {trans }}$, respectively. The former is highly stabilized due to $\left(\mathrm{C}^{\wedge} \mathrm{N}\right)$ chelation. Thus, $\mathbf{C C}_{\text {trans }}$ is calculated to be $54.4 \mathrm{~kJ} \mathrm{~mol}^{-1}$ higher in energy than $\mathbf{C}_{\text {trans }}$. We note that $\left(\mathrm{C}^{\wedge} \mathrm{N}\right)$ cyclometalation of $\mathbf{B}_{\text {cis }}$ may precede cis-trans isomerization ( $c f$. Scheme S5, ESI $\dagger$ ). Species $\mathbf{C}_{\text {trans }}$ and $\mathbf{C} \mathbf{C}_{\text {trans }}$ undergo a second oxidative addition to form the same $\mathrm{Pd}^{\mathrm{IV}}$ intermediate $\mathbf{D}_{\text {trans }}$, stabilized by the $\left(\mathrm{C}^{\wedge} \mathrm{C}^{\wedge} \mathrm{N}\right)$ pincer. A species $\mathrm{G}$ with a second coordinated $\mathrm{PPh}_{3}$ 


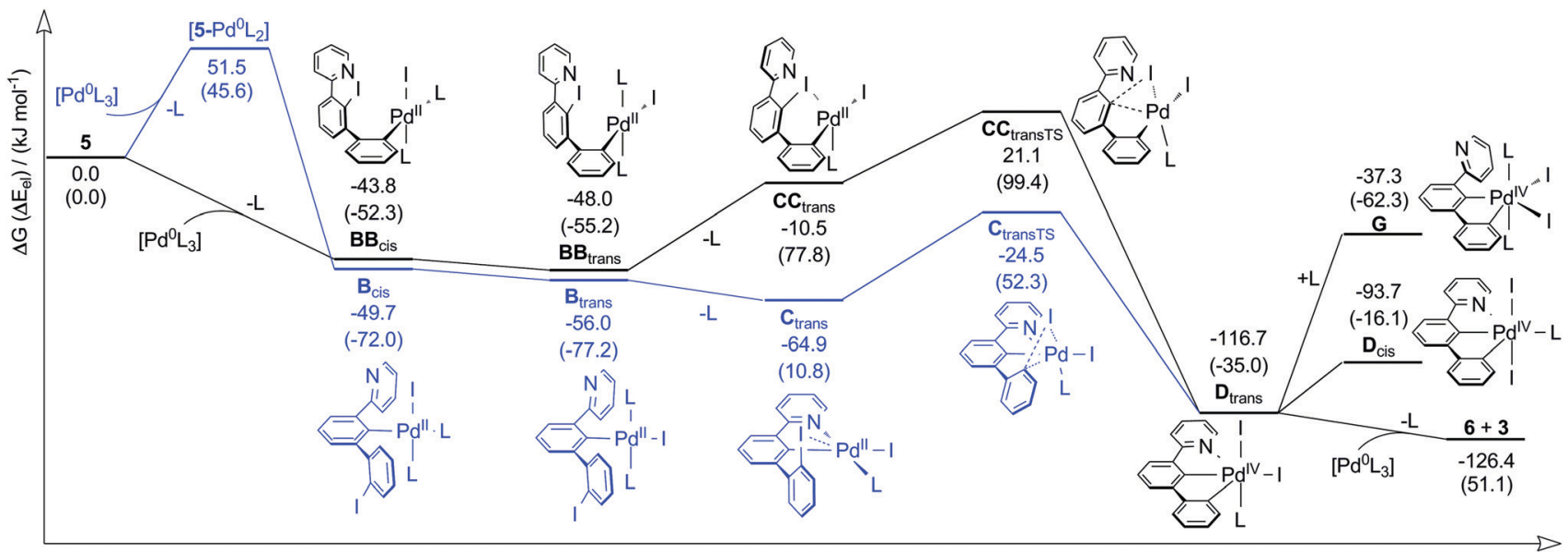

Scheme 2 Mechanism of formation of 3 by comproportionation of intermediate Pd ${ }^{\mathrm{IV}}$ species $\mathrm{D}_{\text {trans }}$ and $\mathrm{Pd} \mathrm{d}^{0}$. The pathway starting by oxidative addition of the central aryl iodide is coloured in blue. All calculations were done on the RI-TPSS-D3(BJ)/def2-TZVP (SMD: toluene) level of theory at 298.15 K and $0.1 \mathrm{MPa}$. $\mathrm{L}=\mathrm{PPh}_{3} . \Delta G$ : Gibbs free energy. Electronic energies $E_{\mathrm{el}}$ are given in brackets. Additional pathways of higher energy intermediates and computational details are given in the Supporting Information.

instead of pyridine is disfavoured by an energy of $79.4 \mathrm{~kJ} \mathrm{~mol}^{-1}$. Thus, the pyridine donor not only lowers the energy of intermediates of the pathway involving central oxidative addition (blue), but also stabilizes $\mathrm{Pd}^{\mathrm{IV}}$ intermediates as well. Finally, $\mathbf{D}_{\text {trans }}$ readily comproportionates with $\left[\mathrm{Pd}\left(\mathrm{PPh}_{3}\right)_{3}\right]$ to form the final products 6 and 3.

Pincer complex 3 shows a blue shifted absorption in the less polar solvent $\mathrm{CH}_{2} \mathrm{Cl}_{2}$ compared to tetrahydrofurane (THF) indicating a charge-transfer character of the first absorption bands (Fig. 3). Slight vibronic structures with line spacings of ca. $1300 \mathrm{~cm}^{-1}$, i.e., the frequency of pincer breathing modes, ${ }^{5,27}$ indicate $\pi \rightarrow \pi^{*}$ IL/MLCT transitions. This assignment is supported by TD-DFT calculations (Section S4, ESI $\dagger$ ).

Complex 3 exhibits intense yellow phosphorescence in the solid-state at room temperature with a quantum yield of $10 \%$. This finding underlines the extraordinary electronic impact of the non-palindromic pincer since palladium complexes luminescent at room temperature are rare. ${ }^{10} \mathrm{An}$ emission lifetime of $0.4 \mu \mathrm{s}$ is indicative for a phosphorescence process. 3 shows no luminescence in liquid solution, probably due to structural distortions in the excited state. ${ }^{28}$ However, in frozen THF solution at $77 \mathrm{~K}$ we observe similar emission with a notably longer lifetime of $370 \mu \mathrm{s}$, thus, standing in line with a decreased vibronic relaxation. The vibronic structured emission of 3 (Fig. 3, red and purple) is comparable to the signature of other $\left(\mathrm{C}^{\wedge} \mathrm{C}\right)$ and $\left(\mathrm{C}^{\wedge} \mathrm{N}^{\wedge} \mathrm{C}\right)$ cyclometalated complexes and indicates a metal-perturbed, pincer-centred $\pi^{*} \rightarrow \pi$ transition. ${ }^{5,27}$ Again, this is supported by TD-DFT calculations (Fig. 4) showing the donor orbital of the $S_{0} \leftarrow T_{1}$ transition being a $\pi^{*}$ orbital of the pincer with major contribution of the pyridine ring.

In summary, a non-palindromic $\left(\mathrm{C}^{\wedge} \mathrm{C}^{\wedge} \mathrm{N}\right)$ complex of palladium with outstanding luminescence properties can be prepared by means of a double oxidative addition - comproportionation sequence of 3-pyridine-substituted 2,2'-diiodobiphenyl 5 and $\left[\mathrm{Pd}\left(\mathrm{PPh}_{3}\right)_{4}\right]$. The presented approach complements already known procedures for the synthesis of pincer complexes and extends the

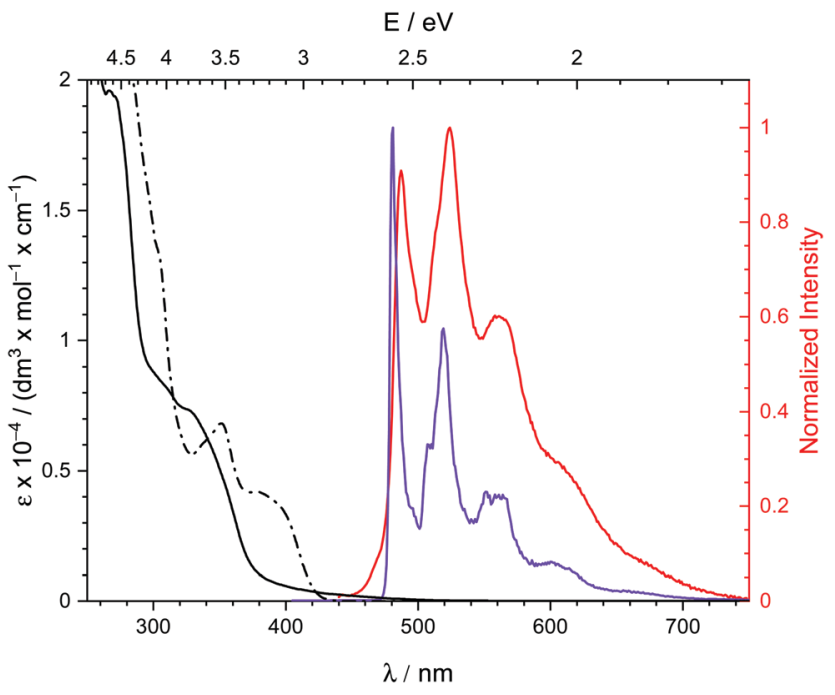

Fig. 3 Absorption spectra of $\left[\left(\mathrm{C}^{\wedge} \mathrm{C}^{\wedge} \mathrm{N}\right) \mathrm{Pd}\left(\mathrm{PPh}_{3}\right)\right]$ (3) in $\mathrm{CH}_{2} \mathrm{Cl}_{2}$ (straight line) and THF (dotted line) and photoemission spectrum in the solid state at $293 \mathrm{~K}$ (red) and in frozen THF solution at $77 \mathrm{~K}$ (purple). Spectra were recorded under oxygen-free conditions.

field of pincers invoking two phenyl donors to palladium. We could illustrate the strong trans influence of the carbon donor of the central phenyl ring of the pincer ligand, which may point to unique catalytic ${ }^{16}$ and biological ${ }^{29}$ properties currently under investigation in our group.

In the future, the presented synthetic principle may prove its viability in the development of pincer complexes invoking other metals than palladium as well; first promising results for nickel are shown in the Supplementary Information (Section S3, ESI $\dagger$ ).

W. F. thanks the Carl-Zeiss Stiftung for a PhD scholarship and the Studienstiftung des Deutschen Volkes for general support. We thank Dr Lilli Neumeier for determination of emission quantum yields and Dr Sergei Lebedkin for the recording of emission spectra at low temperature. 

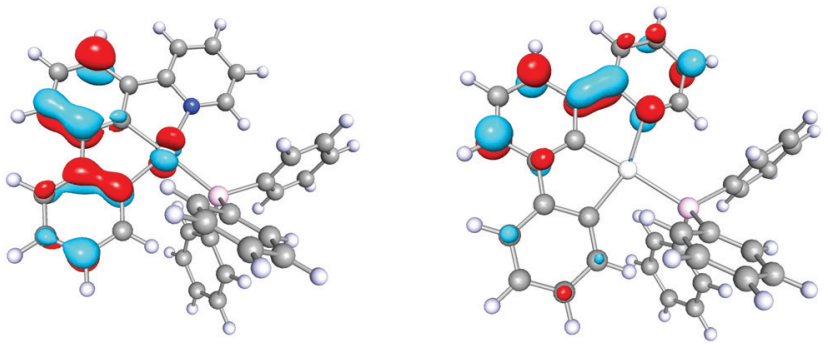

Fig. 4 Spin orbitals (isovalue: 0.06 a.u.) of the phosphorescence transition $\mathrm{S}_{0} \leftarrow \mathrm{T}_{1}$ of $\left[\left(\mathrm{C}^{\wedge} \mathrm{C}^{\wedge} \mathrm{N}\right) \mathrm{Pd}\left(\mathrm{PPh}_{3}\right)\right]$ (3) calculated by Spin-Flip-TDDFT (RI-PWLDA/ def2-TZVP). Orbital contribution (square of orbital coefficients): $99.6 \%$. Calculated $\mathrm{S}_{0} \leftarrow \mathrm{T}_{1}$ transition energy: $-2.42 \mathrm{eV}$ ( $\mathrm{T}_{1}$ optimized structure). Left: $152_{\beta}$ (acceptor orbital), right: $153_{\alpha}$ (donor orbital).

\section{Conflicts of interest}

There are no conflicts to declare.

\section{Notes and references}

\$ We have not determined the transition state of the first oxidative addition, since the oxidative addition of aryl iodides to $\mathrm{Pd}^{0}$ is known to readily happen. ${ }^{30}$

1 G. van Koten, J. Organomet. Chem., 2013, 730, 156; G. van Koten, Pure Appl. Chem., 1989, 61, 1681.

2 G. W. V. Cave, N. W. Alcock and J. P. Rourke, Organometallics, 1999, 18, 1801; V. W.-W. Yam, K. M.-C. Wong, L.-L. Hung and N. Zhu, Angew. Chem., Int. Ed., 2005, 117, 3167.

3 A. M. Ranieri, L. K. Burt, S. Stagni, S. Zacchini, B. W. Skelton, M. I. Ogden, A. C. Bissember and M. Massi, Organometallics, 2019, 38, 1108; Z. Li, Y. Han, Z. Gao and F. Wang, ACS Catal., 2017, $7,4676$.

4 M. C. Tang, A. K. Chan, M. Y. Chan and V. W. Yam, Top. Curr. Chem., 2016, 374, 46; M. A. Baldo, D. F. O'Brien, Y. You, A. Shoustikov, S. Sibley, M. E. Thompson and S. R. Forrest, Nature, 1998, 395, 151; M. Hissler, J. E. McGarrah, W. B. Connick, D. K. Geiger, S. D. Cummings and R. Eisenberg, Coord. Chem. Rev., 2000, 208, 115; E. Turner, N. Bakken and J. Li, Inorg. Chem., 2013, 52, 7344; C. Cebrian and M. Mauro, Beilstein J. Org. Chem., 2018, 14, 1459; C. Lee, R. Zaen, K.-M. Park, K. H. Lee, J. Y. Lee and Y. Kang, Organometallics, 2018, 37, 4639.

5 S. C. Kui, F. F. Hung, S. L. Lai, M. Y. Yuen, C. C. Kwok, K. H. Low, S. S. Chui and C. M. Che, Chem. - Eur. J., 2012, 18, 96.

6 M. Albrecht and G. van Koten, Angew. Chem., Int. Ed., 2001, 40, 3750; P. A. Shaw, G. J. Clarkson and J. P. Rourke, Chem. Sci., 2017, 8, 5547; P. Hamidizadeh, S. M. Nabavizadeh and S. J. Hoseini, Dalton Trans., 2019, 48, 3422; D. Serra, P. Cao, J. Cabrera, R. Padilla, F. Rominger and M. Limbach, Organometallics, 2011, 30, 1885.

7 S. Jurgens, F. E. Kuhn and A. Casini, Curr. Med. Chem., 2018, 25, 437; S. Garbe, M. Krause, A. Klimpel, I. Neundorf, P. Lippmann, I. Ott, D. Brünink, C. A. Strassert, N. L. Doltsinis and A. Klein, Organometallics, 2020, 39, 746; N. Cutillas, G. S. Yellol, C. de Haro, C. Vicente, V. Rodríguez and J. Ruiz, Coord. Chem. Rev., 2013, 257, 2784; C. K. Li, R. W. Sun, S. C. Kui, N. Zhu and C. M. Che, Chem. - Eur. J., 2006, 12, 5253; H. Luo, B. Cao, A. S. C. Chan, R. W. Y. Sun and T. Zou, Angew. Chem., Int. Ed., 2020, 132, 11139.

8 C. Cornioley-Deuschel, T. Ward and A. Von Zelewsky, Helv. Chim. Acta, 1988, 71, 130.

9 M. Maestri, C. Deuschel-Cornioley and A. Von Zelewsky, Coord. Chem. Rev., 1991, 111, 117.
10 M. Ghedini, D. Pucci, G. Calogero and F. Barigelletti, Chem. Phys. Lett., 1997, 267, 341; F. Neve, A. Crispini, C. Di Pietro and S. Campagna, Organometallics, 2002, 21, 3511; P. K. Chow, W. P. To, K. H. Low and C. M. Che, Chem. - Asian J., 2014, 9, 534.

11 P. K. Chow, C. Ma, W. P. To, G. S. Tong, S. L. Lai, S. C. Kui, W. M. Kwok and C. M. Che, Angew. Chem., Int. Ed., 2013, 52, 11775; P. K. Chow, G. Cheng, G. S. M. Tong, C. Ma, W. M. Kwok, W. H. Ang, C. Y. Chung, C. Yang, F. Wang and C. M. Che, Chem. Sci., 2016, 7, 6083.

12 E. Peris and R. H. Crabtree, Chem. Soc. Rev., 2018, 47, 1959.

13 D. A. Rosca, D. A. Smith and M. Bochmann, Chem. Commun., 2012, 48, 7247; D. A. Rosca, D. A. Smith, D. L. Hughes and M. Bochmann, Angew. Chem., Int. Ed., 2012, 51, 10643; L. Rocchigiani, J. FernandezCestau, I. Chambrier, P. Hrobarik and M. Bochmann, J. Am. Chem. Soc., 2018, 140, 8287; N. Savjani, D. A. Rosca, M. Schormann and M. Bochmann, Angew. Chem., Int. Ed., 2013, 52, 874; L. Rocchigiani, J. Fernandez-Cestau, G. Agonigi, I. Chambrier, P. H. M. Budzelaar and M. Bochmann, Angew. Chem., Int. Ed., 2017, 56, 13861.

14 W. K. Kwok, M. C. Tang, S. L. Lai, W. L. Cheung, L. K. Li, M. Ng, M. Y. Chan and V. W. Yam, Angew. Chem., Int. Ed., 2020, 59, 9684; L.-K. Li, M.-C. Tang, S.-L. Lai, M. Ng, W.-K. Kwok, M.-Y. Chan and V. W.-W. Yam, Nat. Photonics, 2019, 13, 185.

15 R. Kumar, A. Linden and C. Nevado, Angew. Chem., Int. Ed., 2015, 54, 14287.

16 H. Beucher, E. Merino, A. Genoux, T. Fox and C. Nevado, Angew. Chem., Int. Ed., 2019, 58, 9064.

17 H. Beucher, S. Kumar, E. Merino, W.-H. Hu, G. Stemmler, S. CuestaGalisteo, J. A. González, J. Jagielski, C.-J. Shih and C. Nevado, Chem. Mater., 2020, 32, 1605.

18 G. S. Ming Tong, K. T. Chan, X. Chang and C. M. Che, Chem. Sci., 2015, 6, 3026; B. Z. Yang, X. Zhou, T. Liu, F. Q. Bai and H. X. Zhang, J. Phys. Chem. A, 2009, 113, 9396; E. S. Lam, W. H. Lam and V. W. Yam, Inorg. Chem., 2015, 54, 3624.

19 J. A. Williams, Chem. Soc. Rev., 2009, 38, 1783; S. Lamansky, P. Djurovich, D. Murphy, F. Abdel-Razzaq, H. E. Lee, C. Adachi, P. E. Burrows, S. R. Forrest and M. E. Thompson, J. Am. Chem. Soc., 2001, 123, 4304; M. S. Lowry and S. Bernhard, Chem. - Eur. J., 2006, 12, 7970; C. K. Prier, D. A. Rankic and D. W. MacMillan, Chem. Rev., 2013, 113, 5322; M. H. Shaw, J. Twilton and D. W. MacMillan, J. Org. Chem., 2016, 81, 6898.

20 W. Feuerstein, C. Holzer, X. Gui, L. Neumeier, W. Klopper and F. Breher, Chem. - Eur. J., 2020, DOI: 10.1002/chem.202003271.

21 J. Vicente, A. Arcas, F. Julia-Hernandez and D. Bautista, Angew. Chem., Int. Ed., 2011, 50, 6896; I. Vicente-Hernandez, M. T. Chicote, J. Vicente and D. Bautista, Chem. Commun., 2016, 52, 594.

22 J. Broggi, T. Terme and P. Vanelle, Angew. Chem., Int. Ed., 2014, 53, 384; N. G. Connelly and W. E. Geiger, Chem. Rev., 1996, 96, 877.

23 V. S. Sergienko and M. A. Porai-Koshits, J. Struct. Chem., 1988, 28, 548.

24 J. A. Labinger, Organometallics, 2015, 34, 4784.

25 S. Grimme, J. Antony, S. Ehrlich and H. Krieg, J. Chem. Phys., 2010, 132, 154104; S. Grimme, S. Ehrlich and L. Goerigk, J. Comput. Chem., $2011,32,1456$.

26 S. Grimme and P. R. Schreiner, Angew. Chem., Int. Ed., 2011, 50, 12639; S. Rosel, C. Balestrieri and P. R. Schreiner, Chem. Sci., $2017,8,405$.

27 S. Fuertes, S. K. Brayshaw, P. R. Raithby, S. Schiffers and M. R. Warren, Organometallics, 2011, 31, 105; R. Wai-Yin Sun, A. Lok-Fung Chow, X.-H. Li, J. J. Yan, S. Sin-Yin Chui and C.-M. Che, Chem. Sci., 2011, 2, 728; B. Fang, Y. Zhu, L. Hu, Y. Shen, G. Jiang, Q. Zhang, X. Tian, S. Li, H. Zhou, J. Wu and Y. Tian, Inorg. Chem., 2018, 57, 14134.

28 C. J. Ballhausen, N. Bjerrum, R. Dingle, K. Eriks and C. R. Hare, Inorg. Chem., 1965, 4, 514; C. Bronner and O. S. Wenger, Dalton Trans., 2011, 40, 12409.

29 X. Riera, V. Moreno, C. J. Ciudad, V. Noe, M. Font-Bardia and X. Solans, Bioinorg. Chem. Appl., 2007, 2007, 98732.

30 M. Busch, M. D. Wodrich and C. Corminboeuf, ACS Catal., 2017, 7, 5643; J. K. Stille and K. S. Y. Lau, Acc. Chem. Res., 2002, 10, 434. 